\title{
Harold and Maude, towards an Aesthetic Hedonism
}

\author{
Christopher Ketcham ${ }^{+}$(iD
}

School of Business, Risk Management and Insurance, University of Houston Downtown,

Houston, TX 77002, USA; chrisketcham@msn.com

+ Retired.

\begin{abstract}
Friedrich Nietzsche's vision for humanity after he declares the death of God is both atheistic and aesthetic, the freedom to live life as it comes (amor fati). Therefore, we can call his existential vision aesthetic atheism. Maude, in the movie Harold and Maude, has a different take on living without God. Rather than take down Christianity, she tries to reform it. She lives freely but is not the intellectual free spirit that Nietzsche hoped would emerge after his proclamation. Rather, her way of existence we can call aesthetic hedonism. She understands that life is contingent, but she loves life for what it is and tries to free others, including animals, saints, and Harold, to experience the same. She does not urge the atheistic turn. I turn to Quentin Meillassoux's notion of cosmological necessary contingency that, while he agrees with Nietzsche that God is at present inexistent, a necessary contingent cosmology cannot rule out the emergence of a divinity. He wonders just what kind of divinity might emerge. I argue that the divinity that might emerge, using Meillassoux's term 'divinology', would depend upon the prevailing attitude, and consider this through both aesthetic atheism and aesthetic hedonism attitudes towards the world.
\end{abstract}

Keywords: aesthetics; atheism; amor fati; contingency; God; Harold and Maude; hedonism; meillassoux; Nietzsche

check for

updates

Citation: Ketcham, Christopher. 2022. Harold and Maude, towards an Aesthetic Hedonism. Religions 13: 9. https://doi.org/10.3390/ rel13010009

Academic Editor: Adam Barkman

Received: 31 October 2021

Accepted: 16 December 2021

Published: 23 December 2021

Publisher's Note: MDPI stays neutral with regard to jurisdictional claims in published maps and institutional affiliations.

Copyright: (C) 2021 by the author. Licensee MDPI, Basel, Switzerland. This article is an open access article distributed under the terms and conditions of the Creative Commons Attribution (CC BY) license (https:/ / creativecommons.org/licenses/by/ $4.0 /)$.

\section{Introduction}

Friedrich Nietzsche thought it necessary to announce the death of God to gain human freedom from oppressive Christian morality (Nietzsche 1974, p. 167, A108). If he could eliminate the theistic progenitor of repressed human freedom, he could then introduce a way to embrace life as it is (amor fati) without the need or desire for an alternative state. Then, humanity would have the freedom to focus on producing a successor to the moral human, a re-naturalized human animal who would declare life and living as the good (Nietzsche 1974, p. 169, A109). ${ }^{1}$ Nietzsche conjured free spirits as virtual companions who were not only good conversationalists, but disrupters, intellects like himself. His vision of this intellectual successor to humanity culminated with Zarathustra, the prophet of amor fati and the intellectual successor to humanity. Unfortunately, like Nietzsche, Zarathustra found few followers to accept his vision of life without oppressive morality (Nietzsche 2005 , p. 6, I, 2).

It was perhaps not Nietzsche's vision but his technique, his bombastic prose to lay waste to entire belief systems that turned off potential followers-for example, his Zarathustra lectures, rather than help others find amor fati themselves, gained him few admirers. ${ }^{2}$ Nietzsche's brand of amor fati can be called aesthetic atheism. Aesthetic atheism understands that life is beautiful, but that extant belief systems that formulate oppressive morality must be summarily eliminated. Though Nietzsche knew that this would take time, he worried that Christian morality might be replaced by nihilism and an attitude that life and living are futile without an afterlife.

Dame Marjorie Chardin, Maude (Ruth Gordon) in Hal Ashby's 1971 movie, Harold and Maude (Script by Colin Higgins), wholeheartedly embraces amor fati, but she also understands that life is contingent. Life is contingent and then you die, which coincidentally, is part of life as well (Ashby 1971). Her understanding of contingency does not embrace 
transcendence, but she does not try to marginalize the Christian Church. Rather, she makes meagre attempts to reform the church. Then, she sets about to help Harold, who symbolizes Nietzsche's dreaded nihilist, learn how to live as an aesthetic hedonist, her brand of amor fati, modestly distinct from Nietzsche's aesthetic atheism. Maude's aesthetic hedonism begins with her understanding of the contingency of life without transcendence (a process that requires the ever-after and a permanent non-contingent soul that transcends life itself). What kind of contingency this might be requires careful consideration.

This question of contingency Quentin Meillassoux considers in extremis, that even the so-called laws of nature are contingent, and the universe could suddenly wink out without explanation (Meillassoux and Badiou 2008, pp. 62-63). ${ }^{3}$ Meillassoux returned to Hume's problem of induction, that, for example, we cannot conclude from the observation and measurement of supposed stable laws of physics that they will indeed always be stable. Meillassoux proposes a "speculative solution" (Meillassoux and Badiou 2008, p. 85). This involves unlinking cause and effect, where it is no longer assumed that there is a necessity for identical causes to produce identical effects (Meillassoux and Badiou 2008, p. 85). In other words, Meillassoux will not rule out the possibility for anomalies even in what physics has revealed as a stable universe. He says, "For experience can only inform us about the present or the past, not the future. It may tell us that a law exists, or is suseptible to verification in the same way in which it has existed or been verified in the past, but it cannot establish that this law will continue to be verified in the future" (Meillassoux and Badiou 2008, p. 87). If contingency is necessary, then what we call orderly processes that stand the test of time cannot be called necessity, because things are bound to change, perhaps even without forewarning. ${ }^{4}$ Many will object to this idea, and rightly so. However, contingency as necessity opens the possibility for a divinity emerging in the future, even if we agree with someone like Nietzsche that God does not presently exist. 'What might constitute that divinity', Meillissoux asks next?

While, like Nietzsche, Meillassoux sees God as inexistent, he is not prepared to deny the possibility of a divinity (Meillassoux 2008, p. 275). Michael O'Neill Burns explains this proposition; "This thesis rests on the assertion that while we can clearly argue that god does not currently exist, we have no reason to believe that he could not one day exist, and thus the notion of a God-to-come is philosophically tenable" (Burns 2010, p. 326). How could Meillassoux deny the possibility of a divinity if everything is necessarily contingent? He wonders, if the laws of the universe should rupture, what might we hope for in the emergence of a divinity, a divinology (his neologism) that eschews both atheism and theism (Meillassoux 2008, p. 275)? The Abrahamic religions teach that God is in and with all of us. Buddha nature gives every sentient creature the power to awaken. What if this power to create a divinology is within each of us? I suggest that Maude's brand of amor fati, aesthetic hedonism, is just such a space between atheism and theism that accepts the contingency of life. Agreeing with Nietzsche, Maude's aesthetic hedonism embraces life to the fullest without requiring a God, but at the same time does not require Nietzsche's atheism. Maude' is a different version of a Nietzschean free spirit.

\section{Results}

The results begin with a summary of the movie, then an analysis of Nietzsche's free spirit and Maude as a different kind of free spirit. Following that are discussions of Nietzsche's aesthetic atheism, God or godless, Maude's aesthetic hedonism, and her suicide. This study concludes with an exploration of Meillassoux's divinology comparing the differences between an emergent 'god' in Nietzsche's aesthetic atheism vs. Maude's aesthetic hedonism.

\subsection{Plot Summary}

The plot for Harold and Maude involves a May-December love affair. Harold is a twenty-something-old man in a young man's body. Maude is a seventy-nine-year-old youthful free spirit in an old woman's body. Harold fakes elaborate suicides for his mother 
(Vivian Pickles) and attends funerals and interments of people he does not know, dresses in black, and drives a hearse. His mother wants him to grow up. First, she arranges dates for him so that he can marry and settle down. He performs elaborate fake suicides for his dates who become terrified because of his antics. His mother has him see a psychiatrist, his uncle the army officer, and later a priest, all of whom do nothing for Harold. Harold is simply not interested in the 'traditional' roles of adulthood, for he has no life. He is obsessed with death. Maude also attends funerals and interments for people she does not know but this is because she is curious about those who died and is preparing herself for her own death and takes her own life on her eightieth birthday. We learn only snippets about Maude's past. She has been married, the camera shows us a holocaust tattoo on her forearm which the film does not further address. She has been a radical demonstrator, but beyond that we know little about her past. We do gain some understanding of her relationship to the past. She keeps keepsakes that have meaning for her, but she dismisses these with, "It's all memorabilia, but incidental and not integral, if you know what I mean" (Ashby 1971). She has taken photographs out of picture frames so they do not haunt her. When she lapses into a brief reminiscence about her past, she quickly concludes it with, "But, that was all ... before ..." (Ashby 1971). She becomes quiet but rebounds quickly, dismissing an umbrella she used defensively in her protest days. Harold asks if she still protests, to which she responds, “Oh, yes! Every day. But I don't need a defense anymore. I embrace! Still fighting for the Big Issues but now in my small, individual way" (Ashby 1971). Maude does not engage in Freudian repression; this is not a pathological suppression of the past to reduce the pain of it. Rather, Maude has her past all around her, but she does not covet it. Nor does she obsess about the future, which in fact is short, as she will take the pills that will end her life the next day. In a way, Maude sees the world through unorthodox Buddhist eyes, living life as it unfolds without continually returning to the past to obsess over it.

We only see Maude with Harold, not her life outside of their relationship. However, we see Harold in his life before Maude and when he is not with her. I suggest that this is intentional. We are to witness Harold's emergence from nihilist to aesthetic hedonist. While Maude serves as the instrument through which Harold will accomplish this emergence, she will not be with him when he makes the transformation. She becomes the moment for Harold. We only have her when she is with Harold and are not privy to her life outside of that relationship, just as we are given only abbreviated insight into her past before Harold. Like Harold, we are to let Maude go and not obsess over her life or her passing.

\subsection{Free Spirits}

Michael Shedlin, in his contemporaneous review of Harold and Maude, says that the movie is about freedom where Maude is a free spirit (Shedlin 1972, p. 51). Nietzsche envisioned his free spirit as, "[a] spirit that has become free, that has again taken possession of itself" (Nietzsche 1996, x, Introduction by Richard Schacht). William C. Parmerleau argues that Maude is a Nietzschean free spirit, and the movie shows this, "[w]ith a blend of gravity and lightheartedness appropriate to a discussion of Nietzsche's views on freedom and creativity" (Pamerleau 2009, p. 193). R. Lanier Anderson explains the free spirit in terms of autonomy: "Autonomy is central to the rare form of strong individuality he praises: the free spirit he idealizes is supposed to be independent from custom and tradition; she 'creates herself' precisely in the sense of giving herself values or laws of her own; she has "independence of the soul'" (Anderson 2012, p. 204). In her discussion of a field of sunflowers, Maude shows Harold how each is different even in a sea of sameness. As we see in the movie, she is quite independent from custom and tradition, stealing cars, and painting smiles on the dour faces of saints.

I agree that Maude embodies the spirit who has taken possession of herself. However, she is not the intellectual, analytical, and critical free spirit that Nietzsche envisioned as explained by Richard Schacht that begins with: 
[t]he repudiation of 'all romantic mendacity', and its replacement by the cultivation of the intellectual conscience and analytical, critical and interpretive abilities of the 'free spirit' he was attempting to become and conjure among his readers by his own example. (Nietzsche 1996, xvii, Introduction by Richard Schacht)

Nietzsche's free spirit, the lover of life, love of fate, what he called amor fati emerges in three books, Human All too Human (1878), Daybreak (1881), and The Gay Science (1882). Nietzsche collectively associated these three as a 'free spirit series' (Nietzsche 1996, xxvii, Translator Introduction). He originally dedicated Human All too Human to Voltaire, in the spirit of enlightenment thinkers everywhere (Nietzsche 1996, ix, Translator Introduction). Above all, Nietzsche was a disruptive thinker, suspicious of the status quo and of philosophical 'truths.' Towards that end, he was not above inventing characters to help him espouse his critique of humanity and human psychology. He said that he conjured 'free spirits' to help him through his chronic physical troubles, and who were to him, "[b]rave companions and familiars with whom one can laugh and chatter when one feels like laughing and chattering, and whom one can send to the Devil when they become tedious - as compensation for the friends I lacked" (Nietzsche 1996, p. 6, I, 2). However, he saw more for these free spirits than imaginary companions, "That free spirits of this kind could one day exist, that our Europe will have such active and audacious fellows among its sons of tomorrow and the next day, physically present and palpable and not, as in my case, merely phantoms and hermit's phantasmagoria" (Nietzsche 1996, p. 6, I, 2). These would be truly enlightened philosophers like himself who both could and would question 'truth' and seek new avenues for knowledge:

[w] free spirits' first have to become' adventurers and circumnavigators of that inner world called "man", as surveyors and [measurers] of that "higher" and "one [above] the other" that is likewise called "man"-penetrating everywhere, almost[!] without fear, disdaining nothing, losing nothing, asking everything, cleansing everything of what is chance and accident in it and as it were thoroughly sifting it. (Nietzsche 1996, xviii, Translator Introduction, and Nietzsche's first preface, Emphasis in original)

Nietzsche's free spirits are intellectuals, adventurers who explore human sensibilities in an effort to better define what it means to be human. The free spirit is hierarchically higher than 'man' and represents a non-Darwinian evolutionary step he will later introduce in the last aphorism of his book four of his Gay Science as Zarathustra, his ubermensch (Nietzsche 1974, p. 274, A342). Above all, this higher being would be much like him, intellectual, curious, industrious, and adventurous in the more cerebral sense, a questioner of everything. Nietzsche wanted there to emerge a kind of aesthetic atheism, where all are free to be without the ethical burden of Christian theology. Babette Babich explains Nietzsche's vision of the aesthetic:

Because science is art (and not the artistic antipode according to the usual schematism of conceptual opposites), the task of acknowledging the contributions of invention or art to nature, the task of re-aestheticizing science, works backward upon the presuppositions of the first primary task, namely the challenge of creating oneself as a work of art. (Babich 2001, p. 241)

With the death of God, Nietzsche has no intention of denigrating spirituality; rather, he reformats spirituality in terms of art and aesthetics and imagines that science can be re-aestheticized. However, the primary mission in life, before all other endeavors, is the molding of an aesthetic self. This is a naturalized self, a de-anthropomorphized self, a self free to create what is possible to create. Babich continues:

Nietzsche proposes to reconcile nature and culture, and that is, to make of humanity a deliberate work of art and this, of course, is what Nietzsche names the grand style. This project at once affirms our place in nature and our disposition as artists of conception, and, sensation/perception. (Babich 2001, p. 244) 
I maintain that Maude, perhaps even more so than Nietzsche's Zarathustra, represents a more realistic picture of what might emerge as the successor to humanity, one who not only lives the life of a free spirit, but helps others to embrace amor fati. However, before considering Maude's aesthetic hedonism, we must first develop an understanding of Nietzsche's aesthetic atheism.

\subsection{Nietzsche's Aesthetic Atheism}

Central to Nietzsche's work is the critique of morality. In On the Genealogy of Morality, he explores the history of morality and discovers that morality is not something that emerges from nature, but is the province of the ruling elite who declare themselves good and all others bad (Nietzsche 2006, p. 11, First Essay, 2). Such an abstraction is unsupportable if the fundamental condition of humanity as human animal is to be free. As Nietzsche explains, his critique is not of power but of morality that saps power, "Are we virtue, we immoralists?-Just as little as anarchists harm harming princes. Princes sit securely on their thrones only after they've been shot at. Moral: morality must be shot at" (Nietzsche 2000, p. 160, Twilight of the Idols (36)). Nor does Christianity fare any better, for they take their vision of morality from the words of God who promises: that if humans repress certain freedoms they will be granted an end to human suffering and be reunited in heaven with God after death. Nietzsche explains his re-naturalization project, "Our own wild nature is the best place to recover from our un-nature, from our spirituality" (Nietzsche 2000, p. 156, Twilight of the Idols (6)). The spirituality of which Nietzsche speaks of recovering from is Christianity.

Power and control are the weapons used to maintain the morality of the noble; the threats and promises of God are the weapons used to maintain the morality of Christianity. Nietzsche's solution to the Christian moral problem is to declare the death of God, both undermining the morality of the church and making transcendentalism impossible. While the declaration of the death of God ends any hope of transcendence, Nietzsche's complaint is not with the transcendental per se, but with the restrictions that Christianity requires in life to achieve an afterlife in heaven. For Nietzsche, the world as we experience it is all we have. He says, "It would not make any sense to fabricate a world 'other' than this one unless we had a powerful instinct for libelling, belittling, and casting suspicion on life: in that case, we would be using the phantasmagoria of an 'other', a 'better' life to avenge ourselves on life" (Nietzsche 2000, p. 170, Twilight of the Idols, Reason in Philosophy (6)). Nietzsche complains that in Christianity, the will to life is not dominant, but "[t]hat the will of God is dominant in the destiny of a people, an individual, which is to say it punishes and rewards depending on the degree of obedience" (Nietzsche 2000, p. 23, The Antichrist (26)). However, Nietzsche does not put the blame directly on God, but on the priests of the church: "The realty behind this pitiful lie is: a parasitical type of person who thrives at the expense of all healthy developments of life - the priest -, abuses the name of God: he gives the name 'kingdom of God' to a state of affairs where the priests determine the value of things; he gives the name 'will of God' to the means used to reach or maintain this state ... " (Nietzsche 2000, p. 23, The Antichrist (26)). Like the nobles who declare themselves good and all others bad, Nietzsche sees the priests positing similar restrictions against human will and the will to life, replacing the will to life with a will to death and the afterlife.

Rather than try to reconstitute another transcendental state (his complaint about creating a different world), he fills the void with a declaration of human freedom to live life as it unfolds, where amor fati is both love of life but also love of fate, the contingent nature of existence as a natural creature. Nietzsche is optimistic about life, not pessimistic like Schopenhauer or Socrates. He says of Socrates, "Socrates wanted to die: -Athens did not give him the poisoned drink, he took it himself, he forced Athens to give it to him" (Nietzsche 2000, Twilight of the Idols, Socrates (12)). Rather, Nietzsche determines to scrub such negative thinking from his thoughts. He says, "I want to learn more and more to see as beautiful what is necessary in things; then I shall be one of those who make things beautiful. Amor fati: let that be my love henceforth! I do not want to wage war against what 
is ugly" (Nietzsche 1974, p. 223, A276). ${ }^{5}$ Beatrice Han-Pile explains amor fati, "[i]t requires us to love a potentially repellent object (as fate entails significant negativity for us) and this, in the knowledge that our love will not modify our fate (Han-Pile 2011, p. 224)". For Nietzsche, this also means living without God.

\subsection{God or No God?}

Rather than declare God's inexistence (at the present time), as does Meillassoux, Nietzsche espoused an atheism that banishes God from the present and in any future state. ${ }^{6}$ If, for the moment, we can accept Meillassoux's notion of necessary contingency that allows for the emergence of some form of divinity, then Nietzsche's radical atheistic turn precludes such an emergence. The prophet of amor fati, Nietzsche's Zarathustra, makes it his mission to convince a very skeptical world that God is dead and Christian moral thinking has been obviated as a result ((Nietzsche 2005, p. 12, Prologue (3) 3)). Unfortunately, Zarathustra is not a good prophet, for he gains only one possible follower, a dying tightrope walker who takes Zarathustra's message of a life well lived, a life that involved risk taking was worth it after all ((Nietzsche 2005, p. 19, (7) 7)). Others simply laugh at Zarathustra, and even his higher men, the sycophants who follow after him, Zarathustra abandons in the end because they have never believed his message. Nietzsche molded Zarathustra in his image-intellectual, challenging, bombastic, a lecturer rather than a listener. Someone who would direct his will to power to forcefully challenge and change the world. Inadvertently, the consequences of Nietzsche's efforts towards this end were embraced by the Nazis as evidence that such efforts were exactly the tactics and methodology the Third Reich needed to prove the Aryan was superior to all other races. The Nazis then realized that the use of unbridled power (as they interpreted), as purportedly espoused by Nietzsche, validated their aggression towards the world. Many have shown that Nietzsche was no Nazi nor anti-Semite, but his dialectic could be read that way. ${ }^{7}$ Nietzsche's aesthetic atheism and Maude's aesthetic hedonism embrace the beauty of life even in harsh times. Nietzsche experienced grave illnesses and he was rejected by most of his peers. Maude experienced the holocaust and death of loved ones.

We begin to see Maude as someone who sees life not through the lens of death but through the possibilities of life, whatever the result. When she paints smiles on the saints in the church she reasons that the saints have endured, the blessed mother suffered the loss of her son, but the saints have wrought miracles, and the blessed mother birthed and raised the son of God. Later, Harold asks Maude if she prays. She says no, she communicates with life (Ashby 1971). She has no need to commune with God because presumably God holds little meaning for her. For her, life and living well hold meaning for her. Her brand of hedonism is not the pursuit of pleasure at any cost, hoarding things or money; rather, it is to pursue life for what it can provide the living for as long as life is possible, but understanding that death, a part of life, is inevitable. While quite intelligent, she seeks not the intellectual pursuits of Nietzsche, but the pursuits of living well, and this includes experiencing the world aesthetically and caringly. She tells Harold that she has liberated pet shops and she feeds the birds. Later, she steals a car and she and Harold transplant a wilting sidewalk tree into the forest where it can breathe again (Ashby 1971). To her, stealing a car is just borrowing it because she never keeps it-contingency means that we can never own property; we are mere custodians. In a field of flowers, she says she most would like to change into a sunflower. Harold looks around and comments that they are all the same. Maude demurs, saying there are no two alike, implying that there is beauty in difference in a world that is nothing but change (Ashby 1971).

To help Harold break out of his nihilism, she encourages him to act spontaneously and eventually he does, something that likely in his ordered but macabre existence he has never done before. She is teaching Harold the nature of contingency, that things are not linear nor static in the world. She asks Harold whether he plays an instrument. He does not, so she gives him a banjo. Harold teaches himself to play. Maude has been introducing Harold to the aesthetics of life for some time, explaining the importance and history of 
certain curiosities in her converted railroad car home and plying him with ginger pie and oat straw tea. Learning the banjo appears to be the thing that snaps Harold from his obsession with death and turns him towards the embrace of amor fati and Maude's aesthetic hedonism. However, Harold must endure one final test of his resolve before he makes the transformation, Maude's suicide.

\subsection{Maude's Aesthetic Hedonism}

There are many similarities between Nietzsche's aesthetic atheism and Maude's aesthetic hedonism. Both are naturalistic in the sense that power comes from personal action that eschews institutional restraint (Maude, property laws; Nietzsche, Christian morality). Maude's objection to personal property is that nothing can be possessed, even life itself. Everything is change. One of Nietzsche's objections to the Church is that it imposes morality that is death affirming, rather than life affirming. Both seek an existence discovering ethic that embraces a natural aesthetic that is worth preserving and enhancing through effort, e.g., Maude rescuing the tree; Nietzsche's Dionysian, who engages in aesthetically pleasing and affirming natural practices. Both see nature as the source for their expression and moral guidance. Both are affirmatively optimistic. Nietzsche embraces life and his own work while suffering not only infirmities, but the rejection of his work by his peers. Maude only hints at the suffering she has endured, including loss of loved ones and the holocaust experience. Despite suffering, not only do both Nietzsche and Maude endure, they appear to thrive when confronted with adversity, powering through without looking back-engaging with the now to take advantage of and experience the full opportunity of the moment.

I see two distinctions between Nietzsche's aesthetic atheism and Maude's aesthetic hedonism. First, Nietzsche's aesthetic comes without God and God's institutional morality. Maude has no God; the world contains all the spirituality she needs. Rather than declare God dead and the Church with it, Maude would just as soon re-naturalize the Church into becoming aesthetically hedonistic. Aesthetic hedonism is not anti-deistic. Rather, aesthetic hedonism embraces that which nature emerges and if nature should emerge something like a god, like all other parts of nature, this god should be both embraced and celebrated. Meillassoux argued for this middle way between theism and atheism as Michael O'Neill Burns explains, "The religious person is not willing to concede that while God may exist now, he may soon perish; and the atheist will not concede that while God currently doesn't exist, he may one day soon come into existence. In each case the position leads to a dogmatic metaphysics predicated on a necessary existence or non-existence" (Burns 2010, p. 327). Such dogma it was Meillassoux's mission to undo. Maude's aesthetic hedonism I believe is towards such a middle way.

The second difference is less striking, but has to do with the nature of and expression of power. As Daniel W. Connor explains:

Nietzsche's appeal here to a subjective measure of organic activity-notoriously, one's "feeling of power" need not correspond to one's actual capacities or prospects for the exercise of power-thus allows him to introduce a qualitative variable into his alternative theory of life. An organism strives above all to discharge its accumulated stores of strength, but it also does so in such a way that promises to maximize its attendant "feeling of power." (Connor 2009, p. 533)

The feeling of power can be seen through different lenses. Nietzsche's will to power is engaged to respect the bounds of nature, but in an effort to improve nature, accentuate and amplify. Great music, architecture, and the other arts and science can be used to improve humanity. Yet, Nietzsche is coy about declaring the necessity for establishing firm values for goals, aspirations, or even what greater achievement means. As Henrik Rydenfelt explains, "His expressions of his ethical stances are not (at least wholly) without any attempt to convince his readers to give up such moralities and values that do not advance their fundamental aspirations and, instead, choose or create such values that would result in greater achievement" (Rydenfelt 2013, p. 222, Emphasis in original). Rather, 
will directed towards what emerges in life is where Nietzsche is trying to lead. Choosing greater achievement or advancement of fundamental aspirations or some combination of both is situational and not categorical. Power for power's sake is not where Nietzsche is heading as Rydenfelt explains, "Nietzsche attributes no intrinsic value to (the achievement of) power, but claims instrumental value to what increases power" (Rydenfelt 2013, p. 214). A subtle difference emerges between Nietzsche's focus and Maude's focus. Maude, it seems, uses that which increases her power to help others discover ways to increase their own power. Maude seems more collaborative than Nietzsche or his avatar, Zarathustra. Zarathustra's assistance is demonstrative, instructive, rather than helping the other learn the value of power through their own means. Nietzsche is talking through Zarathustra, and while Zarathustra delivers his message to common people, Nietzsche, in the body of his work, is delivering his message to the intellectuals, those who may quickly recognize its meaning. Maude's use of her power to help Harold exemplifies what Lev Vygotsky called 'The Zone of Proximal Development' in learning, "It is the distance between the actual developmental level as determined independent problem solving and the level of potential by development as determined through problem solving under adult guidance or in collaboration with more capable peers" (Vygotsky 1978, p. 86, Emphasis in original). Maude is continually assessing where Harold is in his thinking, asking him, as she did with the sunflowers to think about difference, rather than sameness, but then she stands aside when Harold begins to act spontaneously, tumbling down a hill. An example might help clarify the difference between Nietzsche's Zarathustra and Maude. Zarathustra/Nietzsche would explain to a child how to ride a bike and stand aside while the child tried; Maude would stay close at hand, encouraging and commenting while the child tried, letting go and hanging back when the child finds her balance.

While Nietzsche embraced work and creativity, his work was more towards the elite and intellectual rather than brute effort. Gary Yeritsian explains Nietzsche's aesthetic critique of capitalism of his day as, "Nietzsche described industrial work as a form of enslavement, denouncing it in aphorism 18 of the third essay of On the Genealogy of Morals as ' $[\mathrm{m}]$ echanical activity and what goes with it-such an absolute regularity, punctilious and unthinking obedience, a mode of life fixed once and for all, fully occupied time'" (Yeritsian 2019, p. 230, Emphasis in original). In this aesthetic critique, Nietzsche echoes Marx's critique of the work rules and conditions imposed by capitalist society. Thus, 'fully occupied time' negates the possibility to engage personal creative efforts. Nietzsche's critique of capitalism confirms his dissatisfaction with controlling institutions (factory/church), preferring independence and creativity over conformity. However, what Nietzsche is less clear about is how do we as industrial beings engage with the aesthetics of the world without unduly compromising nature. Maude's aesthetic hedonism is just as nature invasive, but in a different way. It is about righting wrongs both to humans and nature itself, done by humans. It is corrective in nature rather than Nietzsche's constructivism. Her feeling of power is also aesthetically driven, but it is an interpersonal feeling, one that seeks to help others restore and maximize their own feelings of power. Thus, her discharge of strength and her feelings of power are, in part, towards the other.

What can we say about Nietzsche's own relationship to the other? Zarathustra gives us some idea, speaking to the sun, "You great star, what would your happiness be if you had not those for whom you shine" (Nietzsche 2005, p. 7, Zarathustra's Prologue, Section 1). Zarathustra is a sharing thing, just like the sun that shares its warmth. For Zarathustra, this is a sharing of me and my ideas which I have given as gifts to humanity, much like a prophet gives the gift of divine wisdom to those who will listen. Maude puts the other first, trying to discover what it is that the other needs. She asks Harold questions, like do you dance, or do you play an instrument? She does not begin dance lessons, and when she hands Harold the banjo, she does not demand anything from him. She is helping Harold find his own way of expressing and using his power to gain an understanding of what feeling of power he will aspire to. Through much practice, Harold uses his will to power to play basic chords on the banjo. 
While Nietzsche puts the nihilistic plight of humanity in the hands of the priests of death, Maude places the blame on misguided human activities that tend to put both people and nature into cages where they can be controlled. Both Nietzsche and Maude see the problems that the misuse of power can bring, and what power can do if used creatively and constructively to improve human existence. Maude is more mindful of non-interference in natural processes. What Maude does is correct the problems of human interference in nature - the tree planted in the sidewalk by humans; human inhumanity to others (her resistant protests) through the positive use of personal will. While Nietzsche seeks to re-naturalize humans, he speaks mostly of the human condition. Maude would like to see all of nature re-naturalized.

\subsection{Suicide}

Harold and Maude develop a relationship that becomes romantic, but this is a brief romance. On her eightieth birthday, Maude takes pills that will end her life. Suicide ought to be an anathema to Nietzsche's amor fati, love of live as it unfolds. In fact, Maude's attitude towards death aligns with Nietzsche's. Arthur Burton et al. explain Nietzsche's position, "Nietzsche views death, not as a mere event or inevitable termination of life, but as a free act similar to other matters of choice" (Burton et al. 1972, p. 313). This comports with Nietzsche's general understanding of the will to power that extends even to choosing one's own time of death. In Thus Spoke Zarathustra, Book 1, in the chapter Voluntary Death, Nietzsche outlines his philosophy of death. He says first, "Many die too late, and some die too early. Yet strange sounds the precept: 'Die at the right time!'” (Nietzsche 2005, p. 61, Part 1 (21)). He elaborates on what he means by dying at the right time: "My death, praise I to you, the voluntary death, which comes to me because I want it ... One must discontinue being feasted upon when one tastes best: that is known by those who want to be long loved" (Nietzsche 2005, p. 61, Part 1 (21)). The right time is when the taste of you is still good in the mouths of others, not after you begin to lose flavor. Maude maintains that the right time is at the age of eighty, not before, and not after. She has no intention of altering her plans because she has become romantically involved with Harold. Nietzsche said of the right time, "And when shall I want it? - He that has a goal and an heir, wants death at the right time for the goal and the heir" (Nietzsche 2005, p. 61, Part 1 (21)). She has done all she can to hoist Harold out of the crevasse of nihilism. Maude's hedonism is not about just enduring life, but enjoying life for as long as it is possible to do so. She reasons that eighty is the age beyond which she not only will become a burden but just a creature marking time. Her amor fati is pragmatic and existence must be valuable, or why exist? Yet, Maude has endured the holocaust and all the suffering it wrought, but continues to embrace amor fati until it no longer will become possible to do so. After she reveals to Harold that she has taken the pills, he calls an ambulance that takes them to the hospital. He moans that he does not want to lose her. Maude chides him, what is death, we start dying from the moment we are born (Ashby 1971). She dies and Harold has a decision to make-choose nihilism or amor fati. In obvious distress, he drives his hearse at high speed towards a cliff where we see the vehicle plunge into the rocks far below. Ashby then pans the camera back from the cliff where we see Harold playing his banjo to the off-screen accompaniment of Cat Stevens singing, "If You Want To Be Free Be Free", while dancing a jig of joy at being alive and having had the opportunity to have a relationship with someone as important to him as Maude (Ashby 1971). He has come to embrace contingency, spontaneity, amor fati, and aesthetic hedonism, all the while without having to declare himself atheist.

\subsection{The Promise of Divinology}

Michael Gillespie maintains that Nietzsche understood time to be infinite and matter finite (Gillespie 2017, p. 67). The consequence of this is that in infinite time, finite things, including lives lived, can be repeated exactly-infinitely-something Nietzsche called eternal recurrence (Nietzsche 1974, p. 273, A341). Nietzsche intended to replace the permanent soul that 'should' be moral in order to achieve a transcendental reunion with 
God in heaven with a peculiar eternalism. Nietzsche's cosmological understanding of matter as finite and time as eternal makes it possible for matter to reconstitute the same rock or the same human over and over again, each to exist in the same way it has done before. While this is the same human or rock, there is no permanence as in soul in either. Matter simply reconstitutes the existent and plays out its existence in the same manner over and again. There is no transcendence in peculiar eternalism because death is death and there is no guarantee that the reconstitution will include the identical molecules and atoms that formed the previous iteration of the same.

Nietzsche used this cosmological understanding of the eternal recurrence in a thought experiment where a demon asks how would you react if I told you that your life will endlessly repeat itself without change? Would you become despondent or embrace the thought that you need to live your life as fully as possible because it is the one chance you have to get it right (Nietzsche 1974, p. 273, A341)? This thought experiment performs two tasks for Nietzsche. First, it declares the end to a permanent soul, less of a sledgehammer than the declaration that God is dead. Nietzsche does not deny the notion of 'self', but he sees it in different terms from permanence. As R. Lanier Anderson explains, "Nietzsche presents the self not as identical to the strongest drive, nor as a bundle of drives, but as an ordered structure of drives and Affects" (Anderson 2012, p. 216). Where affects are, "In place of the aim/object structure characteristic of drives, affects are completed by a stimulus object and something like a default behavioural response" (Anderson 2012). Nietzsche's self never coalesces into a permanent object; rather, it is structured by processes (drives and affects) that enable continuous becoming. However, Nietzsche understands the possibility of lapsing into nihilism in the face of such a loss of permanence.

Second, the eternal recurrence offers the listener the opportunity to embrace amor fati. Ridley Aaron explains Nietzsche's project, "The thought of eternal recurrence is supposed, pretty clearly, to supply the lack-or, rather, is supposed to be some sort of test of how well one has learned to value life, the world and so on without slipping into transcendental fantasies" (Aaron 1997, p. 20). Why is this important? As Aaron explains, Christianity implies the existence of an "infinitely meaningful future" (Aaron 1997, p. 21). Rather, Nietzsche wants us to return to existing in and for the present moment. Says Aaron, "And this, of course, is what Nietzsche takes to be his problem: he wants to invest time-the dimension within which the will has its being-with an immanent significance, with a nontranscendental meaning: he wants to make the present matter again" (Aaron 1997, p. 21).

Nietzsche's understanding that matter is finite impairs a necessary contingency argument. Necessary contingency does permit the fulfillment of the demon's thought experiment, but speculates that this eternal recurrence could also end. However, the thought experiment also obviates the notion of free will. There are many things that begin to break down in Nietzsche's cosmology. For example, with finite resources, over time, lives will endlessly repeat but will there ever be any fresh new experiences, or just recycled ones? ${ }^{8}$ Also there is the dilemma that if things endlessly repeat, what was the first instance and what does that mean in context of personal identity? If contingency is necessary, there is no need for finite matter or infinite time because both are contingent and subject to irruption.

Meillassoux challenges the conventional wisdom that the laws of physics are a necessity in the universe. That there is stability in this universe and there has been for billions of years aside, what would be the possibilities for a universe where there is considerable stability but always already the possibility for instability and even the dissolution of socalled rules of physics? What I believe that Meillassoux is advocating is for a universe built from freedom itself and freedom means possibilities on a scale unimaginable to human sensibilities. Such a cosmology would permit the multiverse and the winking in and out of universes without obvious cause. This would be a cosmology, and in agreement with Nietzsche, with a not-now God, an inexistent God, but where there are possibilities for a divinity, but what kind of divinity? Unfortunately in necessary contingency, many kinds of divinity are possible, but what could we hope for? Meillassoux asks, "If one supposes 
granted the real eventuality of emergences in rupture with the present laws of nature, what will be the most singular possible divinity, the most interesting, the most 'noble' in a sense (paradoxically) close to Nietzsche's? Must this future and immanent god be personal, or consist in a 'harmony', a becalmed community of living, of dead, and of reborn" (Meillassoux 2008, p. 275)?

If we understand that Nietzsche was searching for a way to maintain and express human freedom without external shackles of morality and religion, then we can begin to conceive of a form of divinology that can be associated with ways of living through freedom, but in a way that respects and values all life. We are not talking about God as a prime mover because if freedom is established (subject, of course to change in the context of necessary contingency), then the divinity serves in another role. Perhaps as teacher, companion, and inveterate champion of freedom. There would be no Eden and no Adam and Eve to transgress and disobey the creator. Freedom is not free, however, because life invariably involves suffering through the idea that nature itself is contingent, and there is always some threat to existence and thriving. One must use one's will towards the world in order to change it to continue to exist. Suffering, therefore, is the price of freedom-at least for now-in Meillassoux's necessary contingent cosmology. However, this is not an externally imposed suffering; rather, it is the suffering, productive or otherwise, that is a fact of life.

The Abrahamic religions have fashioned a creator God who becomes angry with the disobedience of humanity beginning in Eden, and after being banished from Eden into a contingent existence-into suffering. Humans have God's love but can only enter heaven by obeying God's divine commands. God's priests became the arbiters for God, fashioning codes, rituals, and restrictions to keep humans on the narrow path towards salvation. It was Nietzsche's complaint that God's will dominates humanity where human will should be dominant in the one life we are given. As Maude has demonstrated, humans can engage with the world in ways that comport with worldly practices without codes, penalties, and oppressive rules. Meillassoux envisions the possibility of a divinology emerging in his contingent cosmology but asks what would be the most interesting that could emerge? I suggest that the most interesting emergent divinology depends upon the prevalent attitude in the replacement cosmology.

The contrast in attitudes towards humanity between Nietzsche and Maude is important. Nietzsche frees humanity from will-repressive morality but he addresses his audience as 'we philosophers'. There has been much discussion about his attitude of superiority which I sum with a quote by Yeritsian through Mark Warren, "[t] he Nazi appropriation of Nietzsche, while clearly distorted, was not entirely a misappropriation, given the undeniable affinities between aspects of Nietzsche's thought and Nazi ideology, most notably his vision of the mastery exercised by a cultural elite over the common herd" (Yeritsian 2019, p. 228). His effort, therefore, was towards influencing his intellectual peers and the culturally elite, the artists, the scientists, rather than the common person. His Zarathustra is constructed in that image even as he tries to gain adherents in the villages. The villagers and those considered the elite, the higher men, fail to grasp what he is trying to tell them. Yet, Zarathustra continues to go under to find those who will listen. I do not believe that Nietzsche envisioned Maude.

Harold comes from a wealthy family and has access to anything he might desire. However, he is not the intellectual, the artist, the scientist that Nietzsche sees as his target audience. To Maud, Harold is just another person like herself, but one who must overcome nihilism to become a human. Zarathustra tends to preach down to his audience, and they summarily reject him. Maude encourages Harold to explore the world. Certainly she does correct him, like when she explains that all sunflowers are not alike, they are all different. She then relates that to all humans. Maude is much more inclusive than Nietzsche.

If we take both Maude and Nietzsche and transfer them into Meillassoux's contingent cosmology where God is inexistent but a divinology is possible, what might each want to see emerge? Nietzsche is both enamored with and respects power. Though he wants to end 
repressive morality, he would like the superior to emerge and lead humanity towards a naturalist aesthetic where the will to power can be exercised without undue moral restraint. However, if his effort creates two classes, the elite intellectuals and all others, without some intervening factor or force, would not the elite once again create conditions where they are in charge of determining who or what is good or bad? Even his notion of ubermensch or nonDarwinian evolutionary successor to humanity is towards bifurcating human and successor, towards what end? Might not Nietzsche's divinology reflect his elitism and construct a state where classes rather than noble or serf, priest or commoner, become 'intellectual' and 'all others'? Nature distributes power unequally and this would be no different. It is how power is utilized is the question. Maude's divinology I do not see segregating or separating the intellectual, the elite from the other. Her past life of demonstrations and liberations are not unlike Nietzsche's liberation from oppressive morality, but are towards liberation for liberation sake, not to establish a stronger, more productive elite. Maude's divinology I believe would not judge the other or categorize the other, but free the other to be other without categorical restraints. Maude is a remover of obstacles. I fear Nietzsche's divinology would continue to introduce obstacles for some to become more than they are. With Harold we see Maude's method of obstacle removal. Unlike Harold's mother who tries to align Harold with the conventional wisdom of marriage, military, psychology, and religion to end his nihilism, Maude introduces Harold to life itself. She helps Harold remove the pin of perpetual fake suicides by helping him see life as wonder and possibility, not something as Nietzsche complained is towards death.

While Meillassoux's contingent cosmology allows for anomalous change, it permits processes to run undisturbed for however long that might be possible. Any cosmology that replaces our own that is contingent as well would use the power of contingency and the power of life itself to create changes to its own environment. An emergent anomalous divinology could be a monster that enslaves life or life's successor. However, if a divinology emerges with the cosmology, it would likely reflect the attitude of the cosmology. The implications of this have been considered between Nietzsche's aesthetic atheism and Maude's aesthetic hedonism. If either becomes the dominant attitude, Nietzsche's attitude would likely produce a different emergent divinology from Maude's.

Funding: This research received no external funding.

Institutional Review Board Statement: Not Applicable.

Informed Consent Statement: Not applicable.

Data Availability Statement: Not Applicable.

Conflicts of Interest: The author declares no conflict of interest.

\section{Notes}

1 'The good' versus 'good' to avoid stumbling into G. E. Moore's naturalistic fallacy (Moore 1903, p. 13). Live involves suffering and not all suffering will be 'good'.

2 For example, in Thus Spoke Zarathustra, the phrase 'thus spoke Zarathustra' is repeated nearly ninety times as Nietzsche records Zarathustra's sometimes brief utterances, and sometimes extensive soliloquies. Zarathustra spent ten years in a cave meditating before coming down the mountain to preach amor fati which echoes Christ's lost years presumably as a carpenter before he emerged to deliver his sermons, and Siddhartha's ascetic meditative journey of many years that culminated in his awakening as Buddha. Nor is the irony lost that Zoroaster (Zarathustra) was the first middle eastern cleric to declare there is but one God.

3 There is not time in this brief study to explore the careful process Meillassoux employs to conclude the necessity of necessary contingency which he explores in detail in After Finitude. In Spectral Dilemma, he introduces the possibility for a divinity emerging in the future. With him, this study speculates about the possibilities for such a divinity. Meillassoux's sees his divinology searching for the kind of divinity who is 'most interesting' which, in this study, I associate with Maude's aesthetic hedonism as compared with Nietzsche's aesthetic atheism.

4 The word necessary is problematic in context of contingency that is always already contingent. Contingency, using Nagarjuna's term, must be 'empty' of self-cause and therefore in that context, is not necessary. Necessity without a prime mover is also empty 
of self cause. Nagarguna offers that even emptiness is empty. Therefore, the emptiness of necessity and contingency must also be empty (Nagarjuna and Garfield 1995, p. 91, Jay Garfield commentary).

5 Fati, fate is not fatalism where all in life is preordained. Rather, it is acceptance of one's fate, the good and the bad, suffering and ecstacy, as it unfolds over a lifetime. What has past has been and rather than dwell on what might have been, amor fati considers what is to become. Therefore, amor fati comports with the idea of contingency.

6 Nietzsche makes God contingent. However, he would not, as Meillassoux speculates, give God or God's successor an opportunity to return. His effort was to return human thought to life itself without the need for a sovereign in the form of a divine being to explain how to live.

$7 \quad$ See Walter S. Kaufmann's commentary in: (Nietzsche 1968, 2001).

8 There is considerable critique of the eternal recurrence in the literature. To engage this critique, see, for example: (Nehamas 1980; Čapek 1983; Oger 1997; Tom 2011; Jenkins 2020).

\section{References}

Aaron, Ridley. 1997. Nietzsche's Greatest Weight. Journal of Nietzsche Studies 14: 19-25.

Anderson, R. Lanier. 2012. What is a Nietzschean Self? In Nietzsche, Naturalism, and Normativity. [Electronic Resource]. Edited by Christopher Janaway and Simon Robertson. Oxford: Oxford University Press, pp. 202-35.

Ashby, Hal. 1971. Harold and Maude. Los Angeles: Paramount Pictures.

Babich, Babette E. 2001. Nietzsche's Chaos Sive Natura: Evening Gold and the Dancing Star. Revista Portuguesa de Filosofia 57: 225-45.

Burns, Michael O'Neill. 2010. Chapter sixteen the hope of speculative materialism michael o'neill burns. In After the Postsecular and the Postmodern: New Essays in Continental Philosophy of Religion. Edited by Anthony Paul Smith and Daniel Whistler. Newcastle Upon Tyne: Cambridge Scholars Publisher, pp. 316-34.

Burton, Arthur, Gary Fisher, George P. Guthrie, Kenneth P. Harris, Jerry Jacobs, Janet M. Kaplan, Peter Koestenbaum, Marvin Levinson, Charles Neuringer, and Robert Olson. 1972. Nietzsche on Death: From Thus Spoke Zarathustra. Omega: Journal of Death and Dying 2: 313-17.

Čapek, Milič. 1983. Eternal Recurrence-Once More. Transactions of the Charles S. Peirce Society 19: 141-53.

Connor, Daniel W. 2009. Life and Self-Overcoming. In A Companion to Nietzsche. Edited by Kieth Ansell-Pearson. Malden: Blackwell Publishing, pp. 532-48.

Gillespie, Michael Allen. 2017. Nietzsche's Final Teaching. Chicago: The University of Chicago Press.

Han-Pile, Béatrice. 2011. Nietzsche and Amor Fati. European Journal of Philosophy 19: 224-61. [CrossRef]

Jenkins, Scott. 2020. The Pessimistic Origin of Nietzsche's Thought of Eternal Recurrence. Inquiry 63: 20-41. [CrossRef]

Meillassoux, Quentin. 2008. Spectral Dilemma. Collapse IV: 261-75.

Meillassoux, Quentin, and Alain Badiou. 2008. After Finitude: An Essay on the Necessity of Contingency. Translated by Ray Brassier. New York: Continuum Intl. Pub. Group.

Moore, George Edward. 1903. Principia Ethica. Cambridge: Cambridge University Press.

Nagarjuna, and Jay L. Garfield. 1995. The Fundamental Wisdom of the Middle Way: Nagarjuna's Mulamadhyamakakarika. Oxford: Oxford University Press, Incorporated.

Nehamas, Alexander. 1980. The Eternal Recurrence. The Philosophical Review 89: 331-56. [CrossRef]

Nietzsche, Friedrich. 1968. The Will to Power. Translated by Walter Arnold Kaufmann, and Reginald John Hollingdale. New York: Vintage Books, vol. 960.

Nietzsche, Friedrich. 1974. The Gay Science. Translated by Walter Kaufmann. New York: Random House.

Nietzsche, Friedrich. 1996. Human All Too Human: A Book for Free Spirits (Cambridge Texts in the History of Philosophy). Translated by Reginald John Hollingdale. Edited by Karl Ameriks. Cambridge: Cambridge University Press.

Nietzsche, Friedrich. 2000. The Antichrist, Ecce Homo, Twilight of the Idols, and Other Writings. Translated by Judith Norman. Edited by Aaron Ridley and Judith Norman. Basic Writings of Nietzsche (Cambridge Texts in the History of Philosophy). Cambridge: Cambridge University Press.

Nietzsche, Friedrich. 2001. The Gay Science. Translated by Josefine Nauckhoff. Edited by Karl Ameriks. Cambridge: Cambridge University Press.

Nietzsche, Friedrich. 2005. Thus Spoke Zarathustra. Translated by Clancey Martin. New York: Barnes and Noble Classics.

Nietzsche, Friedrich. 2006. On The Genealogy of Morality. Translated by Carol Diethe. Cambridge: Cambridge University Press.

Oger, Eric. 1997. The eternal return as crucial test. Journal of Nietzsche Studies 14: 1-18.

Pamerleau, William C. 2009. Existentialist Cinema. London: Palgrave Macmillan.

Rydenfelt, Henrik. 2013. Valuation and the Will to Power: Nietzsche's Ethics with Ontology. Journal of Nietzsche Studies 44: 213-24. [CrossRef]

Shedlin, Michael. 1972. Review: Harold and Maude, Hal Ashby. Film Quarterly 26: 51-53. [CrossRef]

Tom, Stern. 2011. Back to the Future: Eternal Recurrence and the Death of Socrates. Journal of Nietzsche Studies 41: 73-82. [CrossRef] Vygotsky, L. S. 1978. Mind in Society. Cambridge: Harvard University Press.

Yeritsian, Gary. 2019. Freedom Above Things: Nietzsche and the Artistic Critique of Capitalism. Critical Sociology 45: 227-38. [CrossRef] 